\title{
KOMBINASI SIRIH DAN KIPAHIT SEBAGAI IMUNOSTIMULAN TERHADAP PENYAKIT Streptococcosis PADA IKAN NILA (Oreochromis niloticus)
}

\author{
Nunak Nafiqoh", Septyan Andriyanto, Hessy Novita, Desy Sugiani, dan Taukhid
}

Balai Riset Perikanan Budidaya Air Tawar dan Penyuluhan Perikanan

Jl. Sempur No. 1, Bogor 16129

(Naskah diterima: 20 Juli 2020; Revisi final: 22 Maret 2021; Disetujui publikasi: 22 Maret 2021)

\begin{abstract}
ABSTRAK
Serangan penyakit yang paling banyak ditemui menyerang kegiatan budidaya ikan nila adalah bakteri Streptococcus agalactiae sebagai salah satu agen penyakit Streptococcosis. Peningkatan sistem imun dari ikan yang dibudidayakan merupakan cara yang efektif untuk menanggulangi masalah tersebut. Salah satu fungsi tanaman obat adalah sebagai imunostimulan, di mana sistem imun akan meningkat terutama saat mengalami wabah penyakit ikan. Penelitian ini di tujukan untuk mengetahui efek penggunaan kombinasi ekstrak tanaman sirih dan kipahit dengan dosis yang berbeda terhadap respons imun bawaan dari ikan nila. Dosis yang digunakan adalah $1 \% 2 \%$ 4\% dan 8\%per $\mathrm{kg}$ pakan pemberian pakan dilakukan selama empat minggu, diikuti dengan uji tantang menggunakan bakteri patogen $\mathrm{S}$. agalactiae. Meskipun tidak terlihat perbedaan yang nyata, namun rerata respons imun hematokrit, eritrosit, leukosit, fagositik oksidase, dan lisosim pada kelompok perlakuan menunjukkan nilai yang yang lebih tinggi dibandingkan dengan kontrol. Perbedaan yang signifikan ditunjukkan oleh sintasan, di mana kelompok perlakuan mempunyai nilai sintasan yang lebih tinggi dibandingkan dengan kelompok kontrol. Hasil tersebut diduga disebabkan oleh kandungan bahan aktif yang terdapat dalam tanaman obat. Sehingga penggunaannya mampu bertindak sebagai sebagai upaya pencegahan dari infeksi bakteri patogen S. agalactiae. Perlu diketahui juga apakah kombinasi yang digunakan mampu bertindak untuk terapi (pengobatan).
\end{abstract}

\section{KATA KUNCl: sirih; kipahit; imunostimulan; streptococcosis; Oreochromis niloticus}

ABSTRACT: Effects of betel and mexican sunflower combination as immunostimulant against Streptococcosis in nile tilapia (Oreochromis niloticus). By: Nunak Nafiqoh, Septyan Andriyanto, Hessy Novita, Desy Sugiani, and Taukhid

\begin{abstract}
Streptococcosis disease in nile tilapia culture is caused by Streptococcus agalactiae, a bacterium commonly found in freshwater systems. Vaccines and probiotics have been used to prevent the disease outbreaks. However, increasing the innate immune system of cultured fish is more effective in preventing the disease. Medicinal plants have immunostimulant properties, which could be used as an alternative prevention measure against Streptococcosis. This research aimed to determine the effects of betel and kipahit combination as immunostimulant against $\mathbf{S}$. agalactiae in nile tilapia. The combinations consisted of four different doses of $1 \% 2 \%, 4 \%$ and $8 \%$ of the plants' extracts per $\mathrm{kg}$ of feed. Feeding experiment was carried out for four weeks, followed by a challenge test using the pathogenic bacteria $\mathbf{S}$. agalactiae. Despite no observable significant differences, haematocrit, erythrocyte, leukocyte, phagocytic oxidase, and lysozyme in the treatment group showed higher values than the control. The treatment groups also had better survival rates than the control group. These results indicate the presence of active compounds within the medicinal plants. In conclusion, supplementation of the plants' active compounds in feed has the potential as immunostimulant agents in tilapia to prevent Streptococcosis disease caused by pathogenic bacteria S. agalactiae. Determining the capability of this plant combination as a therapeutic agent against $\mathbf{S}$. agalactiaeis an interesting future research direction to be pursued.
\end{abstract}

KEYWORDS: betel; kipahit; immunostimulant; streptococcosis; Oreochromis niloticus

\footnotetext{
\# Korespondensi: Balai Riset Perikanan Budidaya Air Tawar dan

Penyuluhan Perikanan.

Il. Sempur No. 1, Bogor 16129, Indonesia

Tel. + 62218313200

E-mail: nunak.nafigoh@kkp.go.id
} 


\section{PENDAHULUAN}

Aktivitas perikanan budidaya dewasa ini menjadi industri yang cukup menjanjikan, hal ini disebabkan karena produk budidaya telah memenuhi kebutuhan bahan pangan berupa ikan segar. Hal tersebut memicu terjadinya intensifikasi kegiatan budidaya di Indonesia dan juga di negara lainnya. Intensifikasi tanpa pengelolaan yang tepat mengakibatkan timbulnya masalah dalam kegiatan budidaya, salah satunya adalah penyakit yang menyerang kegiatan budidaya.

Penyakit yang cukup menjadi kendala dalam kegiatan budidaya adalah penyakit yang disebabkan oleh bakteri sebagai agen. Bakteri penyebab penyakit yang mampu menyebabkan kerugian hingga 30\% $40 \%$ adalah Streptococcus agalactiae, bakteri ini merupakan penyebab utama penyakit streptococcosis pada ikan (Lusiastuti et al., 2016). S. agalactiae adalah bakteri gram-positif yang berbentuk bulat berantai (Streptococci), bersifat non-hemolitik dan hemolitik baik alpha ataupun beta, menyerang hewan akuatik, terrestrial dan mamalia juga manusia, beberapa jenis ikan yang sudah diketahui rentan terhadap serangan bakteri Streptococcus antara lain dari golongan ikan kakap, salmon, belanak, kerapu, trout, dan tilapia (Amal \& Zamri-Saad, 2011).

Pada proses budidaya ikan nila, bakteri Streptococcus merupakan penyebab penyakit utama yang mampu mengakibatkan kerugian yang cukup besar. Indonesia adalah negara kedua terbesar dalam produksi ikan nila setelah Cina Indonesia (Mapfumo, 2018). Sehingga keberadaan penyakit akibat bakteri Streptococcus menjadi perhatian yang cukup besar dari pemerintah. Beberapa cara telah dikembangkan untuk mengatasi penyakit akibat bakteri Streptococcus, antara lain vaksinasi dan probiotik. Namun kekayaan biodiversitas berupa tanaman yang dapat berfungsi sebagai obat sangat sayang untuk tidak dimanfaatkan; selain itu, tanaman obat-obatan banyak tumbuh di sekitar kolam pemeliharaan.

Daun kipahit adalah salah satu tumbuhan perdu yang ada di sekitar kolam pemeliharaan. Tanaman kipahit sendiri merupakan tanaman yang jarang dimanfaatkan oleh manusia, meskipun mengandung senyawa yang dapat bertindak sebagai anti-oksidan, anti-bakteri, dan anti-inflamasi (Chukwuka \& Ojo, 2014). Sedangkan sirih merupakan obat tradisional yang banyak digunakan di Indonesia, dikenal sebagai anti-bakteri, anti-oksidan, dan mempunyai aktivitas imunomodulasi (Pradhan et al., 2013). Kedua bahan tersebut terbukti sebagai anti-bakteri dengan dosis berbeda saat diujikan pada bakteri Aeromonas hydrophila (Nafiqoh et al., 2019).
Beberapastudi tentang penggunaan bahan tanaman obat menunjukkan bukti efikasi dari tanaman obat yang digunakan baik digunakan secara tunggal ataupun kombinasi, namun studi lanjutan menegaskan bahwa kombinasi dari tanaman obat mempunyai efikasi yang lebih baik sebagai obat (Che et al., 2013; Ji et al., 2007). Oleh karena itu, studi ini dilakukan untuk mengetahui prospek tanaman obat sirih dan kipahit yang dikombinasikan dengan dosis yang berbeda sebagai peningkat sistem imun pada ikan nila yang diuji tantang dengan bakteri Streptococcus agalactiae.

\section{BAHAN DAN METODE}

\section{Tanaman Obat}

Tanaman obat berupa daun sirih dan kipahit didapatkan dari Balai Penelitian Tanaman Rempah dan Obat (Balittro), Bogor berupa serbuk kering. Serbuk dikombinasikan dengan perbandingan daun sirih dan kipahit adalah 1:32.

\section{Persiapan Pakan dan Pemeliharaan Ikan}

Tanaman obat serbuk sirih dan kipahit direndam dalam akuades dengan dosis 1, 2, 3, 4, dan 8 g 100 $\mathrm{mL}^{-1}$ akuades selama semalam, kemudian disaring menggunakan kertas saring Whatman $\left(\mathrm{N}^{\circ} 41\right)$ dan disemprotkan pada $100 \mathrm{~g}$ pakan, pakan dikeringanginkan dan disimpan dalam wadah bersih tertutup, sedangkan pakan kontrol merupakan pakan yang tidak ditambahkan tanaman obat.

Ikan nila berukuran $10 \pm 2 \mathrm{~cm}$ dipelihara dalam bak bervolume 40 liter dengan kepadatan 2 ekor $\mathrm{L}^{-1}$. Ikan dipelihara selama empat minggu dengan diberikan pakan perlakuan sebanyak 3\% dari biomassa. Pada akhir pemeliharaan ikan diuji tantang menggunakan bakteri patogen $\mathrm{S}$. agalactiae dan kematian diamati sampai hari ke-4 pasca uji tantang. Setiap kelompok perlakuan dilakukan sebanyak tiga kali ulangan.

\section{Pengambilan Sampel}

Pengambilan sampel dilakukan pada jam ke-24 pasca uji tantang. Sampel yang diambil adalah darah yang diambil menggunakan spuit $1 \mathrm{cc}$, darah dibagi menjadi dua bagian, satu bagian dicampur dengan 3,8\%natrium sitrat sebagai anti-koagulan dan satu bagian didiamkan selama dua jam pada suhu ruang untuk disentrifus untuk koleksi serum, serum yang dikoleksi kemudian disimpan pada suhu $-20^{\circ} \mathrm{C}$ untuk uji lisosim. Sedangkan darah dengan anti-koagulan digunakan untuk analisis jumlah eritrosit, leukosit, dan fagositik oksidase.

\section{Eritrosit dan Leukosit}

Jumlah eritrosit dan leukosit dilakukan sesuai prosedur yang telah dijelaskan oleh Ngugi et al. (2015). 
Untuk menghitung eritrosit, darah yang telah dicampur dengan anti-koagulan dilarutkan dengan Dacie's fluid (1 $\mathrm{mL}$ formaldehyde, $3 \mathrm{~g}$ trisodium citrate, $99 \mathrm{~mL}$ akuades). Sedangkan untuk menghitung leukosit darah yang telah dicampur dengan anti-koagulan dilarutkan dengan Turk's Fluid (1 mL crystal violet; 0,5 mL asam asetat glasial; $100 \mathrm{~mL}$ akuades). Sampel kemudian diteteskan pada hemocytometer dan dihitung di bawah mikroskop. Perhitungan eritrosit dan leukosit mengikuti rumus:

$$
\begin{aligned}
& \text { Eritrosit }=\frac{\text { Jumlah sel } \times \text { Pengenceran }}{0,02} \\
& \text { Leukosit }=\frac{\text { Jumlah sel } \times \text { Pengenceran }}{\text { Volume kamar hitung }\left(\frac{4}{10}\right)}
\end{aligned}
$$

\section{Respons Imun}

Respons imun yang diukur adalah aktivitas lisosim dan fagositik oksidase, aktivitas lisosim diukur menggunakan metode Ellis (1990). Sebanyak $10 \mathrm{~mL}$ serum diinkubasi dalam $190 \mathrm{~mL}$ suspensi Micrococcus lysodeikticus $\left(0,05 \mathrm{M} \mathrm{Na}_{2} \mathrm{H}_{2} \mathrm{PO}_{4}\right.$ dalam akuades steril. Sampel dibaca sesaat penambahan suspensi dan lima menit setelah inkubasi pada suhu $24^{\circ} \mathrm{C}$ dengan panjang gelombang $530 \mathrm{~nm}$.

Aktivitas fagositik oksidase diukur menggunakan nitroblue tetrazolium (NBT) diukur mengikuti metode Kumar et al. (2008). Sebanyak $20 \mathrm{~mL}$ darah dimasukkan dalam sumur 96 -well plate dan diinkubasi selama satu jam pada suhu $27^{\circ} \mathrm{C}$, sumur dicuci menggunakan phosphate buffer saline(PBS) dan ditambahkan NBT sebanyak $20 \mathrm{~mL}$ dan diinkubasi selama satu jam. NBT dibuang dan ke dalam sumur dimasukkan fiksatif berupa $95 \%$ methanol selama tiga menit, diikuti 30\% metanol selama tiga menit. kemudian ke dalam sumur dimasukkan 70 mL DMSO dan 60 mL KOH (1 M). Sampel dibaca dengan panjang gelombang $540 \mathrm{~nm}$.

\section{Uji Tantang}

Uji tantang menggunakan bakteri S. agalactiaeyang merupakan koleksi dari Instalasi Riset Pengendalian Penyakit Ikan (IRPPI), Depok. Bakteri ditumbuhkan dalam media tryptic soy broth (TSB, Oxoid) selama 48 jam pada suhu $30^{\circ} \mathrm{C}$. Kemudian bakteri diencerkan

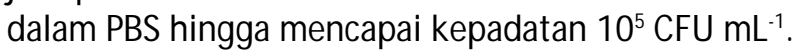
Sebanyak $100 \mathrm{~mL}$ bakteri yang telah diencerkan diinjeksikan secara intramuscular pada minggu ke-4 setelah pemberian pakan. Sintasan dan relative percent survival (RPS) dihitung sebagai berikut:

$$
\mathrm{SR}=\frac{\mathrm{Nt}}{\mathrm{No}} \times 100
$$

di mana:

$\mathrm{Nt}=$ jumlah ikan yang hidup pada akhir eksperimen

No $=$ jumlah ikan yang hidup pada awal eksperimen

$$
\text { RPS }(\%)=\frac{\% \text { ikan pada kelompok perlakuan }}{\% \text { ikan pada kelompok kontrol }} \times 100
$$

\section{Analisis Statistik}

Data yang didapatkan diuji ANOVA dilanjutkan dengan uji Duncan menggunakan statistik menggunakan SPSS ver 18.

\section{HASIL DAN BAHASAN}

Hematokrit merupakan bagian padat dari cairan darah dalam ikan, dengan komposisi terbanyak adalah eritrosit atau sel darah merah. Hasil menunjukkan bahwa penambahan kombinasi ekstrak sirih dan kipahit mampu memelihara jumlah padatan (Gambar 1) sekaligus jumlah eritrosit (Gambar 2) pada kelompok perlakuan. Meskipun nilai hematokrit dan eritrosit tidak menunjukkan perbedaan yang nyata, namun rerata menunjukkan nilai yang lebih tinggi dibandingkan kelompok kontrol. Penelitian mengenai efek infeksi pernah dilaporkan oleh Martins et al. (2008), di mana ikan nila yang diinfeksi menggunakan menunjukkan nilai hematokrit dan eritrosit yang lebih tinggi dibandingkan dengan ikan yang tidak diinfeksi.

Penelitian sebelumnya yang terfokus pada eritrosit manusia menemukan bahwa eritrosit mampu berperan sebagai modulator dari respons imun bawaan (Anderson et al., 2018). Sehingga jumlah sel darah merah yang lebih tinggi pada kelompok perlakuan mengindikasikan bahwa ikan mempunyai sistem pertahanan yang cukup dibandingkan dengan kelompok kontrol. Bakteri S. agalactiaeyang digunakan merupakan bakteri koleksi laboratorium kesehatan ikan yang telah diamati, bakteri ini merupakan bakteri Streptococcus yang bersifat non-hemolitik atau tidak melisiskan eritrosit (Suhermanto et al., 2019), sehingga kemungkinan jumlah eritrosit dari kelompok kontrol tidak dipengaruhi oleh adanya infeksi dari S. agalactiae namun dipengaruhi oleh tidak adanya tanaman obat.

Naiknya jumlah leukosit merupakan respons yang terjadi hampir di setiap adanya serangan infeksi. Hal ini disebabkan bahwa fungsi sel darah putih (leukosit) adalah pertahanan pertama dari tubuh untuk menghalau serangan penyakit yang terjadi (Martins et al., 2008). Penambahan ekstrak tanaman terlihat 


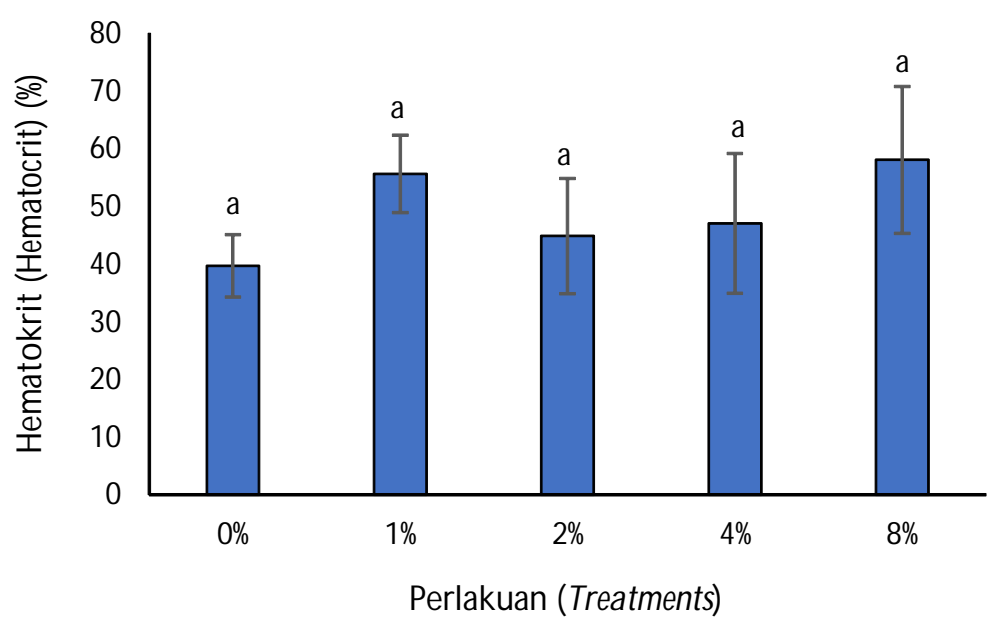

Gambar 1. Nilai hematokrit ikan nila yang menerima perlakuan tanaman kombinasi ekstrak daun sirih dan kipahit setelah uji tantang dengan bakteri S. agalactiae.

Figure 1. Hematocrit value of tilapia fed with a combination of betel and kipahit leaf extract treatment after challenged with $\mathbf{S}$. agalactiae.

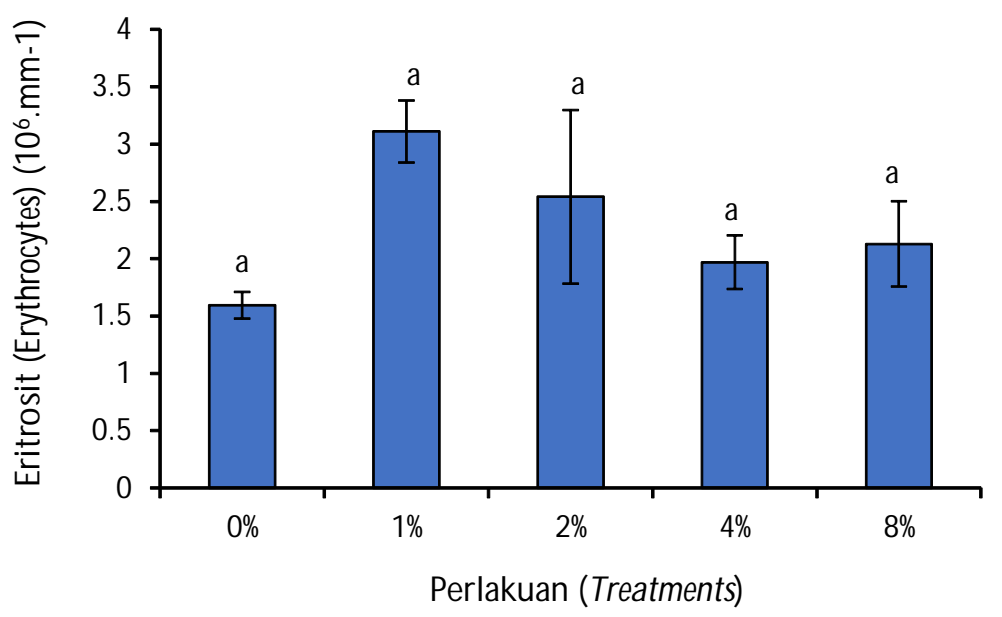

Gambar 2. Jumlah eritrosit ikan nila yang menerima perlakuan tanaman kombinasi ekstrak daun sirih dan kipahit setelah uji tantang dengan bakteri S. agalactiae.

Figure 2. Erythrocyte of tilapia fed with a combination of betel and kipahit leaf extract treatment after challenged with $\mathbf{S}$. agalactiae.

memberikan efek positif pada ikan uji (Gambar 3), hal ini sesuai dengan penelitian sebelumnya yang menunjukkan naiknya jumlah leukosit pada ikan nila yang menerima perlakuan pakan bersuplemen minyak esensial dari citrus limon (Baba et al., 2016). Jumlah leukosit yang naik diduga karena adanya proliferasi sel dari sel dari darah putih yang diproduksi di organ ginjal dari ikan, seperti penelitian yang menggunakan ikan lele sebagai ikan model (Nafiqoh et al., 2019).

Nilai tetrazolium yang menggambarkan aktivitas fagositik oksidase dari ikan nila menunjukkan perbedaan antara perlakuan dan kontrol (Gambar 4).
Hal ini diduga karena jumlah sel darah putih dari kelompok perlakuan cenderung lebih banyak dibandingkan kontrol. Hasil yang sama diperoleh oleh penelitian Baba et al. (2016).

Demikian juga nilai dari aktivitas lisosim yang terdeteksi dari serum, pada kelompok perlakuan cenderung lebih tinggi dibandingkan kelompok kontrol (Gambar 5). Penelitian yang sama menunjukkan adanya kenaikan aktivitas lisosim dari ikan nila yang menerima perlakuan. Lisosim adalah sistem pertahanan humoral dari ikan yang mampu memicu hidrolisis dari dinding sel bakteri, ditemukan 


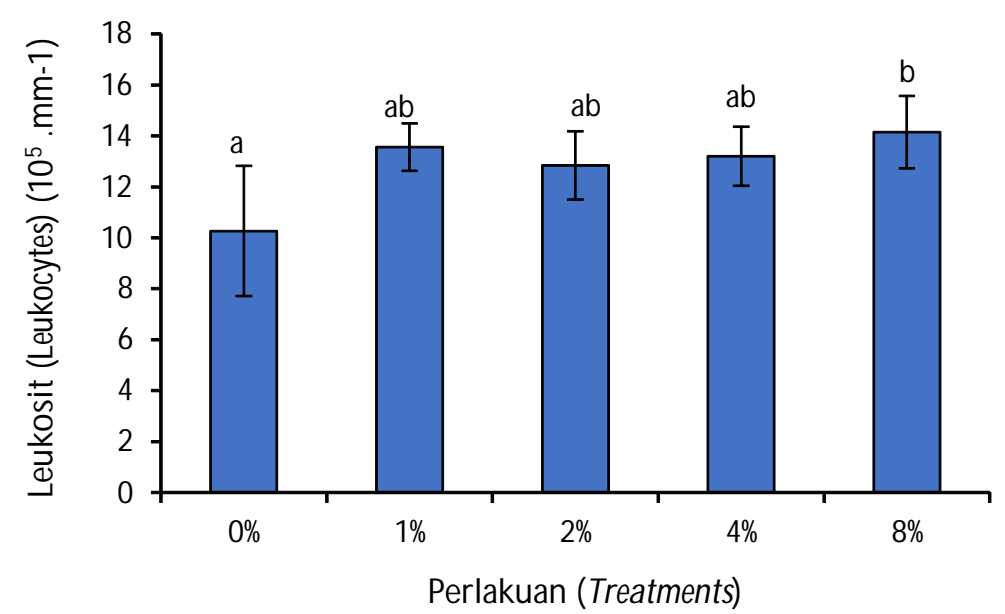

Gambar 3. Jumlah leukosit ikan nila yang menerima perlakuan tanaman kombinasi ekstrak daun sirih dan kipahit setelah uji tantang dengan bakteri S. agalactiae.

Figure 3. Leukocyte value of tilapia received a combination of betel and kipahit leaf extract treatment after challenged with $\mathbf{S}$. agalactiae.

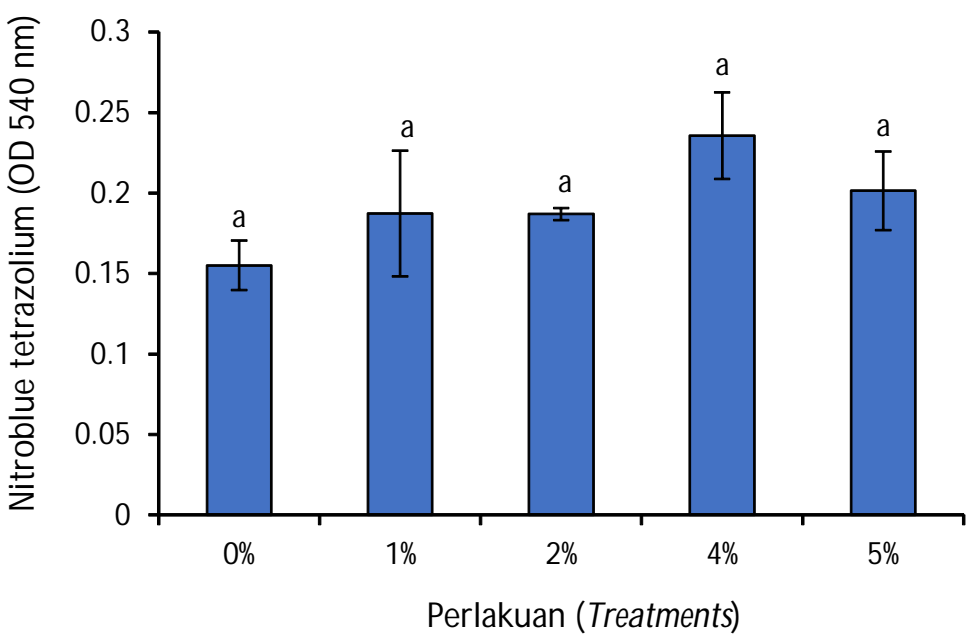

Gambar 4. Nitroblue tetrazolium ikan nila yang menerima perlakuan tanaman kombinasi ekstrak daun sirih dan kipahit setelah uji tantang dengan bakteri S. agalactiae.

Figure 4. Nitroblue tetrazolium value of tilapia fed with a combination of betel and kipahit leaf extract treatment after challenged with $\mathbf{S}$. agalactiae.

pada serum dan lender (mucus) (Vallejos-Vidal et al., 2016). Naiknya aktivitas lisosim akibat penambahan tanaman obat diduga akibat adanya interaksi antara kandungan tanaman obat berupa flavonoid dengan lisosim, perlu dicatat bahwa interaksi ini sangat tergantung pada posisi hydrogen dan glikosil (Yang et al., 2012).

Pada pengukuran pertumbuhan ikan yang menerima perlakuan menunjukkan tidak adanya efek negatif yang biasa terlihat dari pakan yang suplemen tanaman obat, hal ini diduga karena yang digunakan adalah ekstrak dari tanaman sirih dan kipahit di mana serat dari tanaman sudah dieliminasi. Meskipun pertumbuhan panjang dari kelompok perlakuan terlihat tidak berbeda dibandingkan kelompok kontrol (Gambar 6); namun pada pertumbuhan berat, kelompok perlakuan cenderung lebih baik dibandingkan dengan kelompok kontrol (Gambar 7). Penambahan tanaman obat tertentu memang diketahui mampu meningkatkan pertumbuhan seperti penelitian 


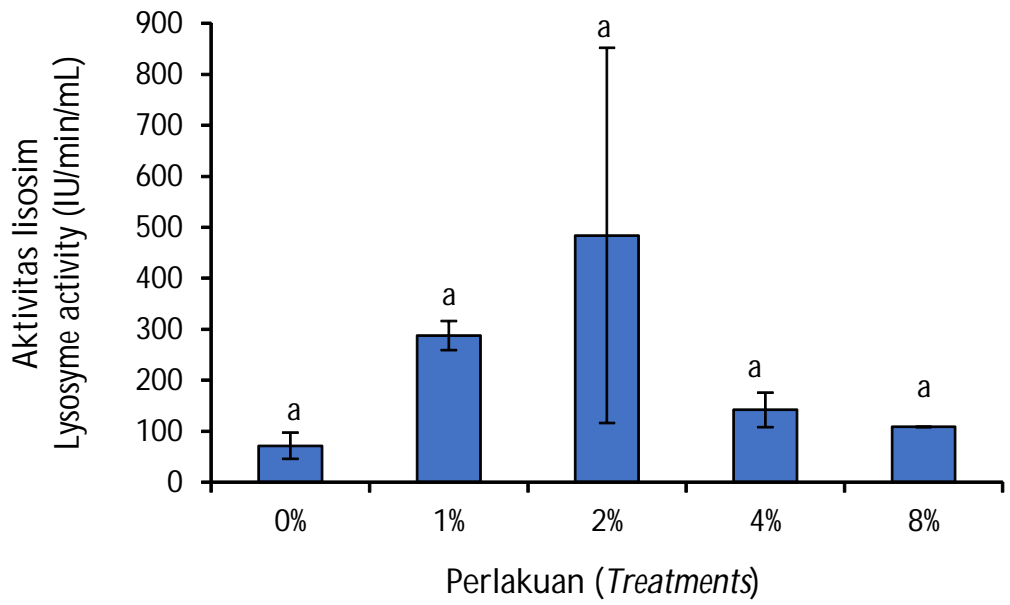

Gambar 5. Aktivitas lisosim ikan nila yang menerima perlakuan tanaman kombinasi ekstrak daun sirih dan kipahit setelah uji tantang dengan bakteri S. agalactiae.

Figure 5. Lysosyme activity of tilapia fed with a combination of betel and kipahit leaf extract treatment after challenged with $\mathbf{S}$. agalactiae.

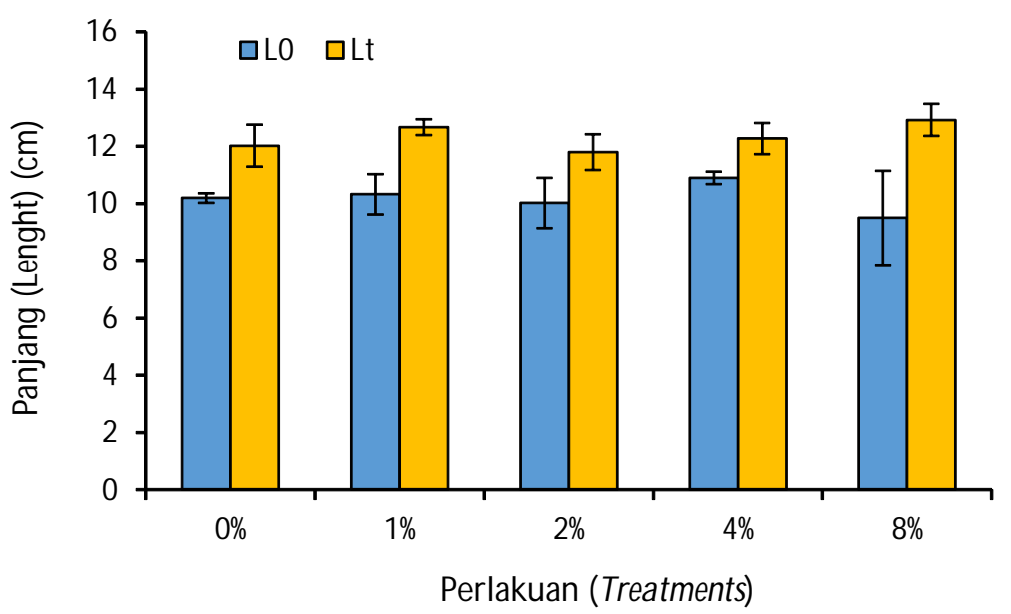

Gambar 6. Pertumbuhan panjang ikan nila yang menerima perlakuan tanaman kombinasi ekstrak daun sirih dan kipahit.

Figure 6. Growth length of tilapia received a combination of betel and kipahit leaf extract treatment.

Abdel-Tawwab et al. (2010) yang menggunakan suplementasi daun teh pada ikan nila. Pertumbuhan yang lebih baik dari kelompok perlakuan diduga naiknya feed intake dari ikan yang menerima perlakuan.

Banyak penelitian yang menunjukkan adanya kenaikan sintasan (Gambar 8) dari ikan yang menerima perlakuan tanaman obat. Kenaikan ini tentu saja dipengaruhi oleh peningkatan respons imun yang menunjukkan adanya kenaikan dibandingkan dengan kelompok kontrol.

Relative percent survival (Tabel 1), menunjukkan bahwa ikan yang menerima perlakuan mempunyai persentase bertahan hidup lebih baik dibandingkan dengan kelompok kontrol. Penelitian menggunakan tanaman daun sirih dan kipahit secara tunggal mampu meningkatkan sintasan relatif hingga 79\% dengan kedua tanaman tersebut dikombinasikan sintasan relatif yang dihitung mampu naik hingga 96\%(Nafiqoh et al., 2019).

Hasil yang didapatkan diduga dipicu oleh bahan aktif yang terkandung pada tanaman obat yang digunakan. Kandungan utama dari daun kipahit adalah asam klorogenat dan sesquiterpenes lactones, keduanya mempunyai aktivitas yang mirip dengan obat antiinflamasi dan antioksidan (Chagas-paula et al., 2011; 


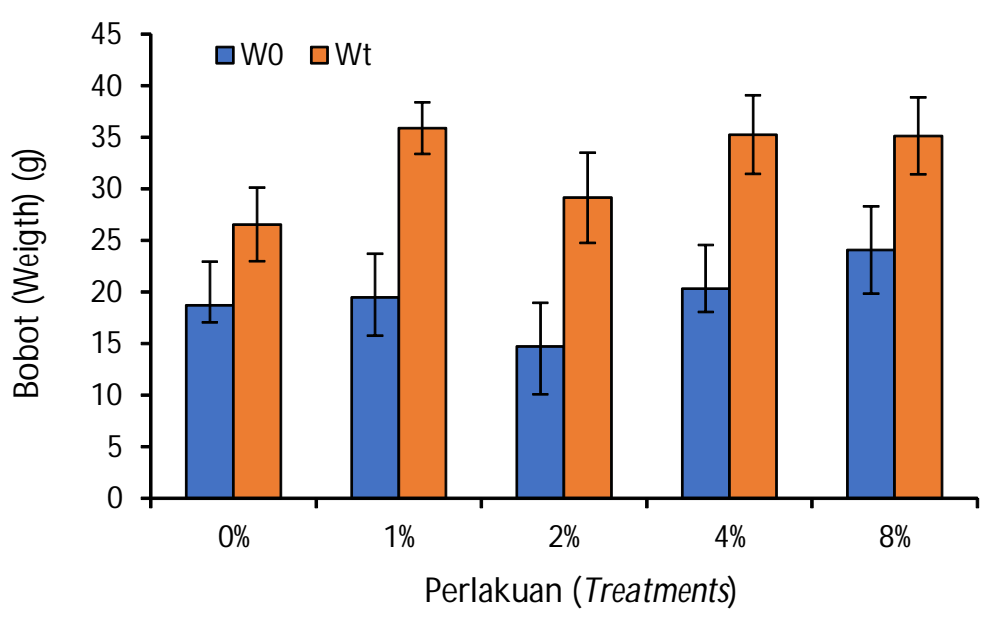

Gambar 7. Pertumbuhan bobot ikan nila yang menerima perlakuan tanaman kombinasi ekstrak daun sirih dan kipahit.

Figure 7. Growth weight of tilapia fed with a combination of betel and kipahit leaf extract treatment.

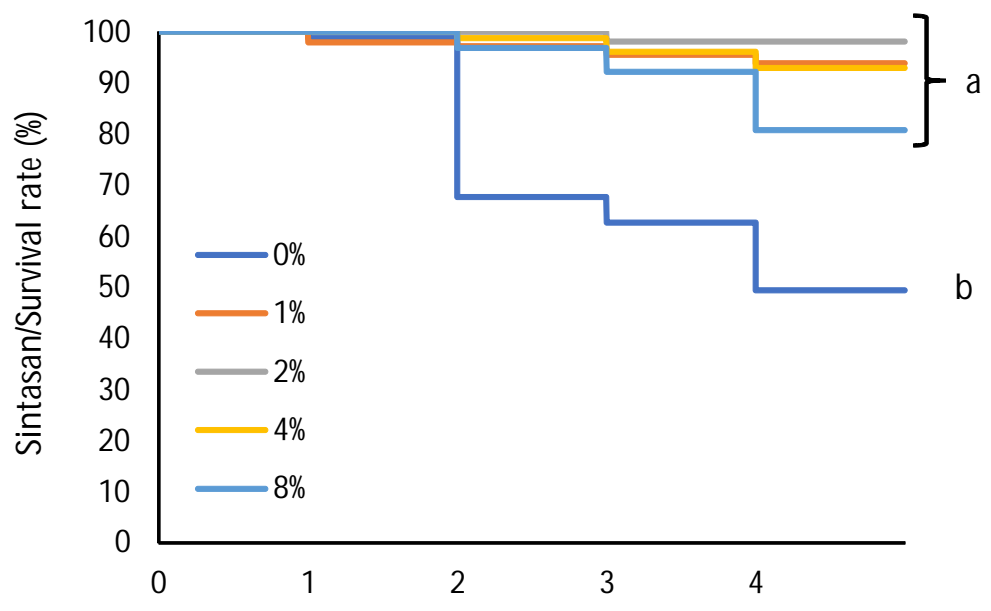

Hari ke- setelah uji tantang (Days post injection)

Gambar 8. Analisis sintasan dari ikan nila yang menerima perlakuan tanaman kombinasi ekstrak daun sirih dan kipahit setelah uji tantang dengan bakteri S. agalactiae.

Figure 8. Survival rate of tilapia fed with a combination betel leaf and kipahit extract after challenged with $\mathbf{S}$. agalactiae bacteria.

Tabel 1. Relative percent survival (RPS) dari ikan nila yang menerima perlakuan kombinasi ekstrak daun sirih dan kipahit setelah uji tantang dengan bakteri S. agalactiae

Table 1. Relative percent survival (RPS) of tilapia fed with a combination betel leaf and kipahit extract after challenged with $\mathbf{S}$. agalactiae bacteria

\begin{tabular}{cc}
\hline Perlakuan (Treatments) & $\begin{array}{c}\text { Persentase kelangsungan hidup relatif } \\
\text { Relative percent survival (RPS) }\end{array}$ \\
\hline $0 \%$ & - \\
$1 \%$ & 87.9182 \\
$2 \%$ & 96.33885 \\
$4 \%$ & 86.03532 \\
$8 \%$ & 80.13287 \\
\hline
\end{tabular}


Husniati \& Sari, 2021). Sedangkan kandungan utama dari daun sirih adalah eugenol yang bersifat sebagai anti-bakteri dan anti-jamur (Prakash et al., 2010; Saxena et al., 2014). Kombinasi anti-oksidan dan antibakteri pada sirih dan kipahit diduga mampu memberikan efek meningkatnya sintasan pada ikan uji, melalui mekanisme naiknya respons imun bawaan dari ikan.

\section{KESIMPULAN}

Penambahan tanaman kombinasi ekstrak daun sirih dan kipahit mempunyai prospek yang cukup baik sebagai imunostimulan pada ikan nila sebagai upaya pencegahan dari infeksi bakteri patogen Streptococcus agalactiae. Semua dosis yang digunakan (1\% 2\% 4\% dan $8 \%$ menunjukkan adanya pengaruh terhadap respons imun bawaan dari ikan yang diamati melalui parameter jumlah eritrosit, leukosit, aktivitas fagositik oksidase, dan aktivitas lisosim, meskipun tidak menunjukkan perbedaan yang nyata. Tanaman herbal yang diberikan mampu meningkatkan sintasan dari ikan uji. Perlu dilakukan penelitian tentang prospek kombinasi sirih dan kipahit untuk pengobatan pada ikan.

\section{UCAPAN TERIMA KASIH}

Penulis mengucapkan terima kasih pada Setiadi, Edy Farid Wadjdy, Johan Afandi, Ardea Kumarasetya, Ahmad Wahyudi, Agung Mulya, dan Hernritzka atas bantuannya selama penelitian berlangsung. Penelitian ini dibiayai oleh DIPA 2019 Balai Riset Perikanan Budidaya Air Tawar dan Penyuluhan Perikanan (BRPBATPP) Sempur, Bogor.

\section{DAFTAR ACUAN}

Abdel-Tawwab, M., Ahmad, M.H., Seden, M.E.A., \& Sakr, S.F.M. (2010). Use of green tea, Camellia sinensis $L$., in practical diet for growth and protection of nile tilapia, Oreochromis niloticus (L.), against Aeromonas hydrophila infection. Journal of theWorld Aquaculture Society, 41, 203-213. https://doi.org/ 10.1111/j.1749-7345.2010.00360.x.

Amal, M. \& Zamri-Saad, M. (2011). Streptococcosis in tilapia (Oreochromis niloticus): A review. Pertanika J. Trop. Agric. Sci., 34(2), 195-206.

Anderson, H.L., Brodsky, I.E., \& Mangalmurti, N.S. (2018). The evolving erythrocyte: Red blood cells as modulators of innate immunity. The Journal of Immunology, 201(5), 1343-1351. https://doi.org/ 10.4049/jimmunol.1800565.

Baba, E., Acar, Ü., Öntao으. C., Kesbiç, O.S., \& Yýlmaz, S. (2016). Evaluation of citrus limon peels essential oil on growth performance, immune response of Mozambique tilapia Oreochromis mossambicus challenged with Edwardsiella tarda. Aquaculture, 465, 13-18. https://doi.org/10.1016/ j.aquaculture.2016.08.023.

Chagas-paula, D.A., Barbosa, R., Oliveira, D., Cristina, V., Gobbo-neto, L., Helena, T., Paula, A., Helena, L., Batista, F., \& Costa, D. (2011). Chlorogenic acids from Tithonia diversifolia demonstrate better antiinflammatory effect than indomethacin and its sesquiterpene lactones. Journal of Ethnopharmacology, 136(2), 355-362. https:// doi.org/10.1016/j.jep.2011.04.067.

Che, C.T., Wang, Z.J., Sing, M., Chow, S., Wai, C., \& Lam, K. (2013). Herb-herb combination for therapeutic enhancement and advancement: Theory, practice and future perspectives. Molecules, 18, 5125-5141. https://doi.org/10.3390/molecules18055125.

Chukwuka, K.S. \& Ojo, O.M. (2014). Extraction and characterization of essential oils from Tithonia diversifolia (Hemsl.) A. Gray. American Journal of Essential Oils and Natural Products, 1(4), 1-5.

Ellis, A.E. (1990). Lysozyme assay. In Stolen, J.S. (Ed.), Techniques in Fish Immunology: Fitc 1 (p. 101-103). Sos Publications. https://books.google.co.id/ books?id= yHIWAQAAIAAJ.

Husniati, H. \& Sari, M.Y. (2021). Kajian: Karakterisasi senyawa aktif asam lorogenat dalam kopi robusta sebagai antioksidan. Majalah Teknologi Agro Industri, 12(2), 7.

Ji, S.C., Takaoka, O., Jeong, G.S., Lee, S.W., Ishimaru, K., Seoka, M., \& Takii, K. (2007). Dietary medicinal herbs improve growth and some non-specific immunity of red sea bream Pagrus major. Fisheries Science, 73(1), 63-69. https://doi.org/10.1111/j.14442906.2007.01302.x.

Kumar, R., Mukherjee, S.C., Ranjan, R., \& Nayak, S.K. (2008). Enhanced innate immune parameters in Labeo rohita (Ham.) following oral administration of Bacillus subtilis enhanced innate immune parameters in Labeo rohita (Ham.) following oral administration of Bacillus subtilis. Fish \& Shellfish Immunology, 24, 168-172. https://doi.org/10.1016/ j.fsi.2007.10.008.

Lusiastuti, A.M., Purwaningsih, U., \& Sumiati, T. (2010). Isolasi bakeri anti Streptococcus agalactiae dari ikan nila (Oreochromis niloticus). Jurnal Riset Akuakultur, 5(2), 237-243. DOI: http://dx.doi.org/ 10.15578/ira.5.2.2010.237-243.

Martins, Ml., Mouriño, Jlp., Amaral, Gv., Vieira, Fn., Dotta, G., Jatobá, Amb., Pedrotti, Fs., Jerônimo, Gt., Buglione-Neto, Cc., \& Pereira-Jr., G. (2008). Haematological changes in Nile tilapia experimentally infected with Enterococcus sp. Brazilian 
Journal of Biology, 68(3), 657-661. https://doi.org/ 10.1590/S1519-69842008000300025.

Mapfumo, B. (2018). Tilapia Trade: Global and Regional Trends. FAO/ASTF GCP/RAF/510/MUL: Enhaching capacity/risk reduction of emerging Tilapia Lake Virus (TiLV) to African tilapia aquaculture. http:// www.fao.org/fi/static-media/M eetingDocuments/ TiLV/dec2018/p13.pdf.

Nafiqoh, N., Sukenda, S., Zairin Jr.M., Alimuddin, Lusiastuti, A.M., \& Avarre, J.-C. (2019). Status kesehatan ikan lele (Clarias gariepinus) yang menerima pakan bersuplemen kombinasi daun sirih, (Piper betler leaf), jambu biji (Psidium guajava leaf), dan kipahit (Tithonia diversifolia leaf). Jurnal Riset Akuakultur, 13(4), 357-365. https://doi.org/ 10.15578/jra.13.4.2018.357-365.

Nafiqoh, N., Sukenda, Zairin, M., Alimuddin, Lusiastuti, A.M., Sarter, S., Caruso, D., \& Avarre, J.-C. (2019). Antimicrobial properties against Aeromonas hydrophila and immunostimulant effect on Clarias gariepinus of Piper betle, Psidium guajava, and Tithonia diversifolia plants. Aquaculture International. https://doi.org/10.1007/s10499-01900439-6.

Ngugi, C.C., Oyoo-Okoth, E., Mugo-Bundi, J., Orina, P.S., Chemoiwa, E.J., \& Aloo, P.A. (2015). Effects of dietary administration of stinging nettle (Urtica dioica) on the growth performance, biochemical, hematological, and immunological parameters in juvenile and adult Victoria Labeo (Labeo victorianus) challenged with Aeromonas hydrophila. Fish and Shellfish Immunology, 44(2), 533-541. https:// doi.org/10.1016/j.fsi.2015.03.025.
Pradhan, D., Suri, K.A., Pradhan, D.K., \& Biswasroy, P. (2013). Golden heart of the nature: Piper betle $L$. Journal of Pharmacognosy and Phytochemistry, 1(6), 147-167.

Prakash, B., Shukla, R., Singh, P., Kumar, A., Mishra, P.K., \& Dubey, N.K. (2010). Efficacy of chemically characterized Piper betle L. essential oil against fungal and aflatoxin contamination of some edible commodities and its antioxidant activity. International Journal of Food Microbiology, 142(1-2), 114-119. https://doi.org/10.1016/j.ijfoodmicro. 2010.06.011.

Saxena, M., Khare, N.K., Saxena, P., Syamsundar, K.V., \& Srivastava, S.K. (2014). Antimicrobial activity and chemical composition of leaf oil in two varieties of Piper betle from northern plains of India. Journal of Scientific and Industrial Research, 73(2), 95-99.

Suhermanto, A., Sukenda, S., Zairin, Jr.M., Lusiastuti, A.M., \& Nuryati, S. (2019). Characterization of Streptococcus agalactiae bacterium isolated from tilapia (Oreochromis niloticus) culture in Indonesia. AACL Bioflux, 12(3), 11.

Vallejos-Vidal, E., Reyes-López, F., Teles, M., \& MacKenzie, S. (2016). The response of fish to immunostimulant diets. Fish \& Shellfish Immunology, 56, 34-69. https://doi.org/10.1016/ j.fsi.2016.06.028.

Yang, R., Yu, L., Zeng, H., Liang, R., Chen, X., \& Qu, L. (2012). The interaction of flavonoid-lysozyme and the relationship between molecular structure of flavonoids and their binding activity to lysozyme. Journal of Fluorescence, 22(6), 1449-1459. https:// doi.org/10.1007/s10895-012-1082-9. 